\title{
Algunos aspectos microestructurales del deterioro del hormigon
}

\section{On some microstructural aspects of concrete deterioration}

\author{
E. A. DRAPER, K. E. WAGNER \\ R. J. Lee Group, Inc., Monroeville, Pennsylvania \\ J. SKALNY \\ Construction Materials Consultant, Timonium, Maryland
}

EE.UU.

Fecha de recepción: 25-XI-93.

\section{$R E S U M E N$}

Hay numerosos procesos que pueden afectar al hormigón de cemento portland. Los más conocidos son: la corrosión de las armaduras, el efecto expansivo del hielo-deshielo, la reacción álcali-árido, el ataque ácido y los problemas que atañen a los sulfatos, incluyendo la formación de ettringita expansiva. Además, el hormigón puede deteriorarse como consecuencia de determinados procesos, entre los que se cuenta el curado. A menudo, más de uno de los mecanismos citados influyen conjuntamente en el daño observado en el hormigón.

El presente artículo revisa brevemente métodos de microscopía óptica y electrónica utilizados para estudiar las causas que motivaron deterioro en el hormigón, y resume algún caso seleccionado; concretamente, se destacan los efectos microestructurales que resultan de mecanismos físicos (por ejemplo, de hielo-deshielo) y químicos (p.ej., reacción álcali-silice; formación de ettringita expansiva). No se hace mención de aspectos relativos a corrosión de armaduras.

\author{
$S U M M A R Y$ \\ There are numerous mechanisms that can lead to \\ deterioration of portland-cement concrete in service. The \\ best known are corrosion of reinforcement, freezing-thawing \\ expansion, alkali-silica reaction, acid attack, and \\ sulfate-related problems, including delayed ettringite \\ formation. Additionally, concrete can deteriorate as a \\ consequence of improper processing, including curing. \\ Often, several of the above mechanisms of deterioration \\ are jointly responsible for the observed damage.
}

This paper briefly reviews the light-optical and electronoptical microscopic methods available to study some of the causes of concrete deterioration, and briefly describes selected case studies. Specifically, microstructural features resulting from physical (e.g., freezing-thawing) and chemical (e.g., alkali-silica reaction, delayed ettringite formation) deterioration of concrete are highlighted. Corrosion of reinforcement is not discussed.

Keywords: concrete durability, microstructure, electron microscopy, alkali-aggregate reaction, delayed ettringite formation, hiqh-temperature curinq, freezinq and thawinq.

\section{INTRODUCCIÓN}

Además de la corrosión de armaduras, los mecanismos de degradación del hormigón, que aparecen con mayor frecuencia, son la pérdida de resistencia debida al fenómeno de hielo-deshielo; el ataque a causa de los sulfatos que contiene el terreno o el agua, y la reacción álcali-árido. En industrias químicas y agrícolas es frecuente la alteración de la pasta de cemento a causa de diversos ataques químicos.

Conjuntamente con otras técnicas experimentales, la microscopía se emplea con frecuencia. Los

\section{INTRODUCTION}

Other than corrosion of reinforcement, the most common mechanisms of concrete degradation are lack of resistance to freezing and thawing of water, degradation of the cement paste in concrete by sulfate-containing soils or waters, and the alkali-silica reaction. In chemical and agricultural industries, decomposition of cement paste caused by various chemicals is common.

In combination with other experimental techniques, microscopic techniques are widely 
desarrollos nuevos en microscopía computerizada -óptica y electrónica-, así como de otras técnicas, permiten en la actualidad una visión más amplia de la estructura de esos materiales, haciendo posible mejorar su conocimiento $y$, posiblemente, la creación de nuevos métodos de ensayo.

\section{DETERMINACIÓN DE MECANISMOS DE DETERIORO DEL HORMIGÓN UTILIZANDO TÉCNICAS DIVERSAS}

El empleo de múltiples técnicas es crucial para determinar la razón de fallos en hormigones o en estructuras de hormigón. La utilización de una única técnica o método no es recomendable, ya que puede llevar a conclusiones incorrectas respecto a la reparación o reemplazamiento de la estructura. Además en tales casos a menudo se llega a situaciones de litigio y puede ser necesario emplear métodos sofisticados complementarios a los métodos normalizados (p.ej. UNE, ASTM, DIN).

En el presente trabajo planteamos brevemente determinados casos de alteración de hormigones que se estudiaron a través de diversas técnicas de microscopía electrónica y óptica, como complemento de las normalizadas de laboratorio. Se incluye microscopía electrónica de transmisión (TEM) y de barrido, tanto por electrones secundarios (SE) como por "backscattered" (BSE). Incidiremos sobre los resultados que se obtienen a través de SEM controlado por ordenador, técnica con capacidad de almacenamiento y de rápida recuperación de la información, incluyendo imágenes, composición (usando espectroscopía de rayos $\mathrm{X}$ ), forma de partículas y morfología de la superfície (1). También se diseñaron portamuestras especiales con los que fue posible la identificación y evaluación de áreas idénticas tanto por SEM como por estereomicroscopía.

\section{IMPORTANCIA DE LA PREPARACION DE MUESTRAS}

La selección de la forma (o formas) de preparar la muestra es crucial. Se pueden obtener informaciones distintas y complementarias utilizando muestras fracturadas, secciones pulidas, láminas delgadas (con o sin impregnación de tintura fluorescente), o TEM de secciones de láminas delgadas. En consecuencia, se han seleccionado técnicas de microscopía electrónica o de microscopía óptica. Las técnicas se representan en la Tabla I (2). used to determine the cause of degradation. New developments in computerized electron-optical microscopy and other techniques now permit a more thorough look at the structure of these materials, thus making it possible to improve our knowledge and, possibly, create novel test methods.

\section{THE DETERMINATION OF CONCRETE DETERIORATION MECHANISMS USING A MULTI-TECHNIQUE APPROACH}

In the forensic evaluation of concrete or concrete structural failure, employment of multiple techniques is crucial. Use of a single test procedure or technique is not recommended because it may lead to incorrect conclusions with respect to the repair or replacement of the structure. In addition, such cases often result in litigation and the use of sophisticated methods may be needed to supplement the important standard tests, such as those of Spanish standards, DIN, or ASTM.

In this overview, we plan to briefly discuss cases of concrete deterioration in which several electron-optical techniques were used to supplement standard laboratory methods. Such techniques included transmission electron microscopy (TEM), and scanning electron microscopy in both secondary electron (SE) and backscattered electron (BSE) modes. We will concentrate on results obtained by computer-controlled SEM, a technique having the capabilities of storage and rapid retrieval of the needed information, including images, composition (by use of $X$-ray spectroscopy), and particle shape and surface morphology (1). Additionally, specially-designed sample holders were used which enable identification and evaluation of identical areas by both SEM and stereomicroscopic approaches.

\section{THE IMPORTANCE OF PROPER SAMPLE PREPARATION}

Selection of proper sample form(s) is crucial. Different and supplementary information can be obtained by using fractured samples, polished sections, thin sections (with/without fluorescent dye impregnation), or TEM thin sections. Consequently, appropriate electron or light-optical microscopic techniques have to be selected. Available techniques are highlighted in Table I (2). 
TABLA I

Método de preparación de la muestra

\begin{tabular}{|l|l|l|}
\hline \multicolumn{1}{|c|}{ Preparación de muestra } & \multicolumn{1}{|c|}{ Técnica analítica } & \multicolumn{1}{c|}{ Información característica } \\
\hline Sección pulida & SEM. microscopía estereoscópica & $\begin{array}{l}\text { Microestructura de la pasta, análisis } \\
\text { químico, estudio de fisuras, reacción } \\
\text { en los bordes, contenido de aire, } \\
\text { clasificación de áridos, relación a/c }\end{array}$ \\
\hline Lámina delgada & UV microscopio petrográfico & $\begin{array}{l}\text { Identificación y característica } \\
\text { microestructurales de la pasta, } \\
\text { muestras fisuradas (preparación } \\
\text { cuidadosa), reacción en bordes }\end{array}$ \\
\hline Superficie de fractura & $\begin{array}{l}\text { SEM, microscopio estereoscópico, } \\
\text { microscopio óptico confocal }\end{array}$ & $\begin{array}{l}\text { Procesos de fractura (árido y pasta), } \\
\text { propiedades mecánicas, relación } \\
\text { espacial de producción de reacción }\end{array}$ \\
\hline $\begin{array}{l}\text { Coloración fluorescente impregnada } \\
\text { en lámina delgada }\end{array}$ & Microscopio con luz UV & $\begin{array}{l}\text { Valoración de muestras fisuradas, } \\
\text { fisuras en áridos, inspección de } \\
\text { huecos, a/c }\end{array}$ \\
\hline Láminas delgadas & TEM & $\begin{array}{l}\text { Información cristalográfica sobre } \\
\text { microconstituyentes, información } \\
\text { química cuantitativa, alta resolución } \\
\text { de la microestructura de la pasta, } \\
\text { composición interfacial }\end{array}$ \\
\hline
\end{tabular}

TABLE I

Sample configuration and obtainable information

\begin{tabular}{|l|l|l|}
\hline \multicolumn{1}{|c|}{ Sample Configuration } & \multicolumn{1}{|c|}{ Analytical Tools } & \multicolumn{1}{c|}{ Typical Information } \\
\hline Polished section & $\begin{array}{l}\text { SEM. Stereo Scopic } \\
\text { Microscope }\end{array}$ & $\begin{array}{l}\text { Paste microstructure, chemical } \\
\text { analysis, crack studies, reaction rims, } \\
\text { air content, aggregate classification, } \\
\text { water-tocement ratio (w/c) }\end{array}$ \\
\hline Optical thin section & $\begin{array}{l}\text { UV/Petrographic } \\
\text { Microscope }\end{array}$ & $\begin{array}{l}\text { Aggregate identification and } \\
\text { characterization, paste microstructure, } \\
\text { crack pattern (careful prep), reaction } \\
\text { rims }\end{array}$ \\
\hline Fracture surface & $\begin{array}{l}\text { SEM, Stereo Optical } \\
\text { Optical Microscope }\end{array}$ & $\begin{array}{l}\text { Fracture process (aggregate and } \\
\text { paste), mechanical properties, spatial } \\
\text { relationships of reaction products }\end{array}$ \\
\hline $\begin{array}{l}\text { Fluorescent dye- } \\
\text { impregnated thin section }\end{array}$ & Microscope with UV Light & $\begin{array}{l}\text { Crack pattern evaluation, cracked } \\
\text { aggregate study, air-void inspection, } \\
\text { w/c }\end{array}$ \\
\hline Thin foil & TEM & $\begin{array}{l}\text { Crystallographic information on } \\
\text { microconstituents, quantitative } \\
\text { chemical information high resolution } \\
\text { of the paste microstructure, interfacial } \\
\text { compositions }\end{array}$ \\
\hline
\end{tabular}


La importancia de una alta calidad en la preparación de las muestras no debe ser sobrevalorada. En el caso de emplear muestras pulidas o láminas delgadas, son los casos en los que conviene una cuidadosa preparación. Esto incluye un cortado apropiado, pegado e impregnación. La figura 1 muestra un típico ejemplo de dos muestras preparadas de diferente manera, en el análisis de muestras de un mismo hormigón, dando como resultado informaciones muy distintas en el estudio por técnicas microscópicas similares.

\section{CASOS ESTUDIADOS}

\section{Daños por hielo-deshielo}

El hielo y deshielo del agua en el hormigón puede conducir a una destrucción total de la estructura en tan solo un invierno. Sin embargo los aditivos aireantes son capaces de proteger de forma adecuada a la mayor parte de la estructura expuesta al ataque, por la incorporación dentro del hormigón de aire homogéneamente distribuido en poros de tamaño adecuado que aportan huecos y que pueden absorber el efecto de la congelación del agua sin producir daños.

Lamentablemente, a causa de la combinación de posibles efectos sobre los procesos de hidatación (procedimientos de mezclado, aditivos, y variables ambientales), ni el total de del aire preciso, ni el tamaño de las burbujas de aire y su distribución son siempre óptimos. Por ello, en climas en los que la temperatura fluctúa alrededor del punto congelación, los daños por las heladas es frecuente; por ello se normaliza el contenido de aire en el hormigón fresco y endurecido para resistir el efecto del hielo-deshielo.

La determinación por microscopía óptica del contenido de huecos se realiza por la Norma ASTM C 457, pero ahora el equipo óptico totalmente informatizado es capaz de determinarlos rápidamente $\left(^{*}\right)$. El empleo de tal instrumentación avanzada es primordial cuando el daño que recibe el hormigón es causado por más de un único mecanismo, cuya situación se encuentra con frecuencia.

Para comparar con las técnicas de microscopía óptica, hemos realizado experiencias con métodos para determinar la distribución espacial de poros por SEM. La figura 2 representa dos aspectos de una distribución de

$\left(^{*}\right)$ por ejemplo: RAPIDAIR Automated Test of Air-Void Distribution in Hardened Concrete (G. M. Idorn Consult, A/S).
The importance of high quality sample preparation cannot be overemphasized. Whether one uses polished or thin sections, it is most important to have them well prepared. This includes proper cutting, lapping, and impregnating. Figure 1 gives a typical example of two differently prepared samples, used in evaluation of the same concrete, resulting in very different information when studied by similar microscopic techniques.

\section{CASE STUDIES}

\section{Freezing-Thawing Damage}

Freezing and thawing of water in the concrete matrix (frost attack) can, in principle, lead to the complete destruction of a structure in a single winter season. However, the widespread use of air entrainment provides protection for most of the structures exposed to frost attack by introducing into the concrete homogeneously distributed, moderately sized air voids providing space in which water can freeze without causing damage.

Unfortunately, due to a combination of possible effects on the hydration processes (mixing procedures, admixtures, and environmental variables), neither the total required air content nor the air bubble sizing and distribution are always at their optimum. Therefore, in climates where the temperature fluctuates around the freezing point, frost damage to concrete is common; so is testing for air content in fresh and hardened concrete and testing hardened concrete for resistance to freezing and thawing.

Optical microscopic determination of the air-void system is covered by ASTM C 457, but fully-computerized optical equipment is now available for its rapid determination $\left({ }^{*}\right)$. The use of such advanced instrumentation is of importance primarily when the damage to concrete is caused by more than a single mechanism, a situation that is not uncommon.

For comparison with optical microscopic techniques, we are experimenting with a methodology for determination of spatial distribution of air voids by SEM. Figure 2 represents two views of a typical air void

(*) e.g., RAPIDAIR Automated Test of Air-Void Distribution in Hardened Concrete (G. M. Idorn Consult, AVS). 


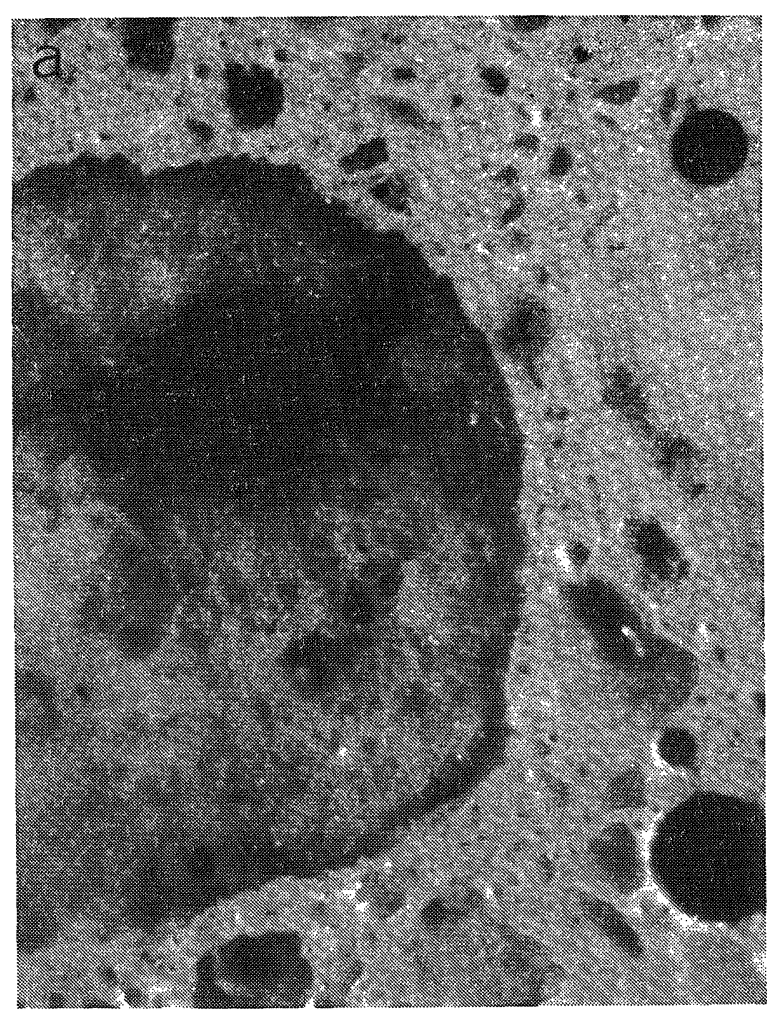

a

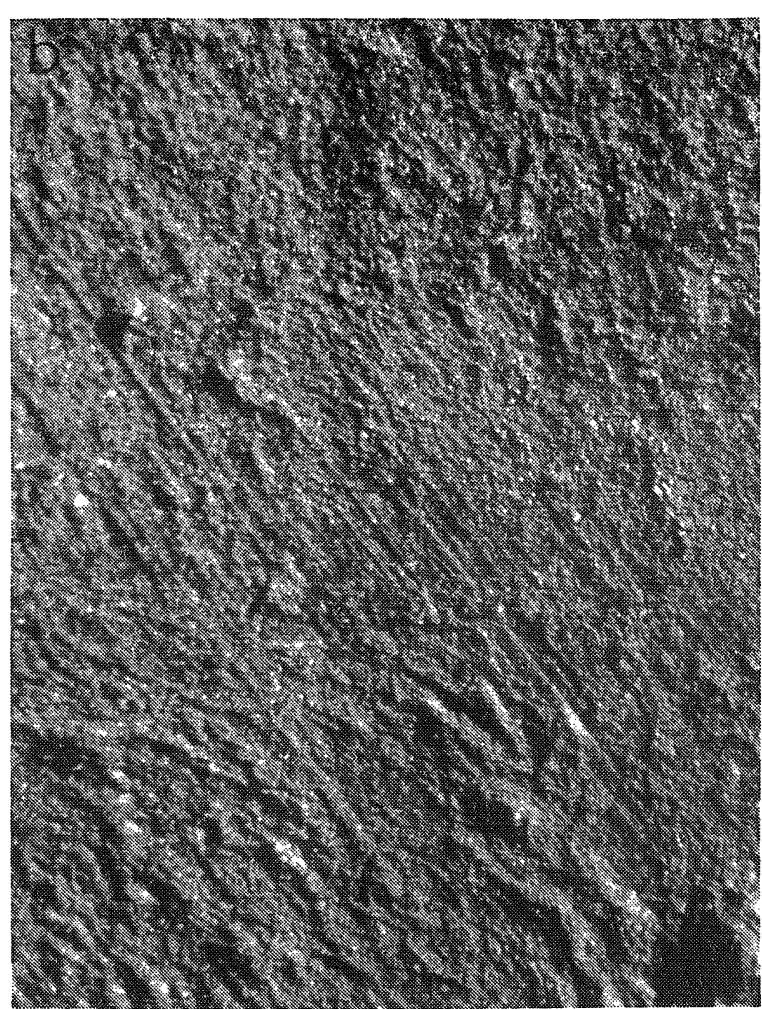

b

Fig. 1.-Superficies preparadas adecuada (a) e inadecuadamente (b). Microscopía óptica. Aumento x 55 .

Fig. 1.-Properly (a) and improperly (b) prepared surface. Light microscopy. Magnification: x 55.

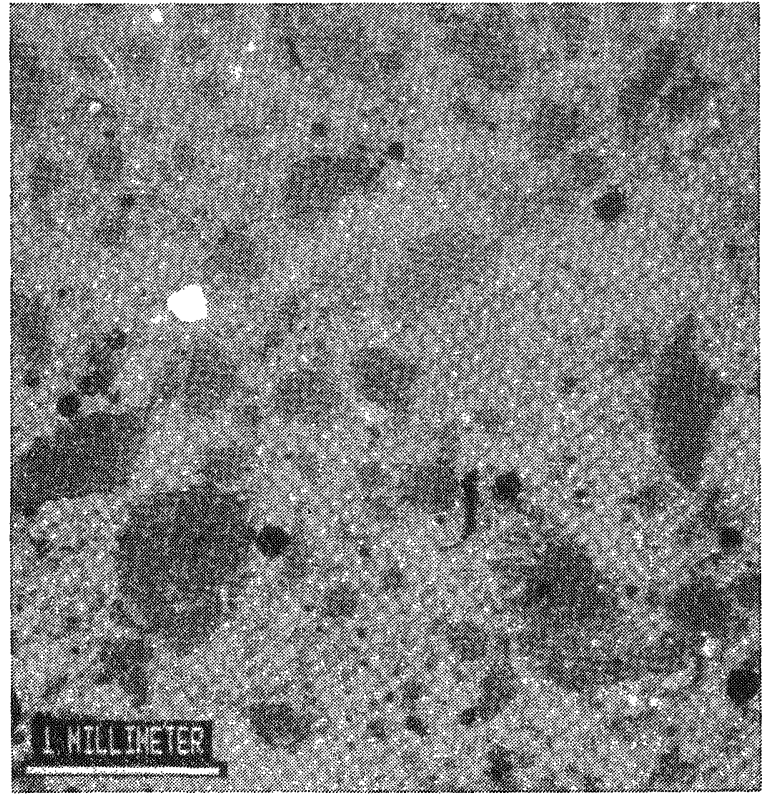

a

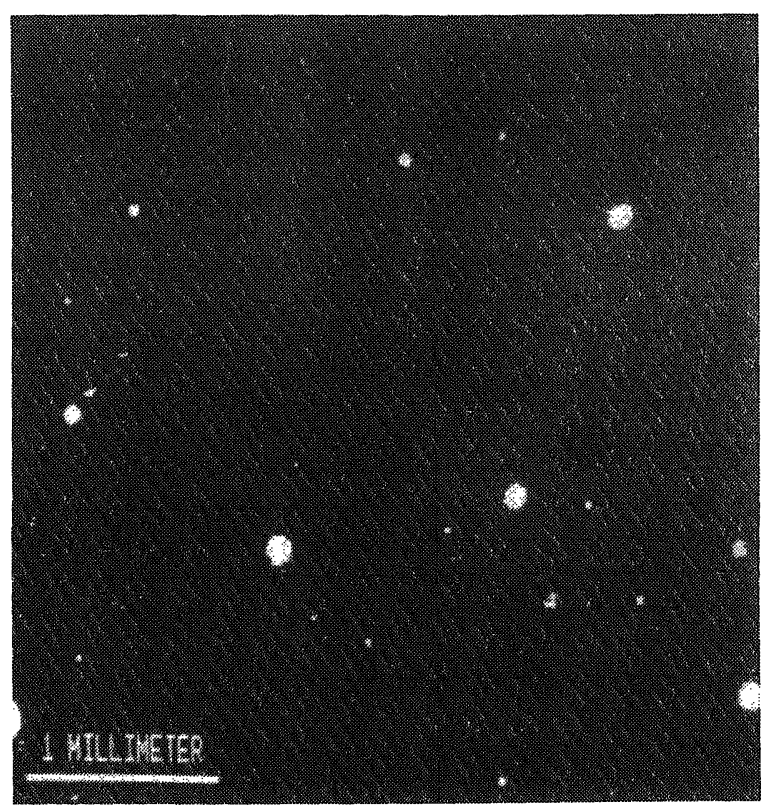

b

Fig. 2.-Distribución de huecos en un hormigón no aireado. SEM.

Fig. 2.-Air void distribution in a non-air entrained concrete by SEM. 
aire típica en una muestra de lámina delgada de un hormigón no aireado, visto a través de SEM (a) y de BSE (b), en fondo oscuro (para mejor observación). El mayor poro de aire observable es de unos $0,1 \mathrm{~mm}$. Utilizando un analizador de imagen binario, el contenido de aire de ese área en particular se halló que era del $0,7 \%$.

La figura 3 muestra aspectos similares para un hormigón con más alto contenido de aire; para el área examinada el contenido en poros se sitúa alrededor del 6,3\%. El máximo poro era de 0,4 mm de diámetro. Con 20 áreas seleccionadas al azar, el porcentaje de contenido de aire para esas muestras era de 1,6 y $6,5 \%$, respectivamente. A menudo, la utilización rutinaria del SEM, como método analítico para determinar huecos, es prohibitiva por su elevado coste. No obstante en ocasiones complejas es conveniente el empleo de la misma muestra (en el caso presente una lámina delgada) para la determinación del contenido de aire, fisuras, microestructura, mineralogía de los áridos, presencia y localización de productos agresivos, etc.; desde nuestra propia experiencia se trata de una metodología analítica ventajosa cuando se utiliza en combinación con procedimientos normalizados. Se está desarrollando un estudio comparativo cuantitativo entre los análisis por SEM y los correspondientes a la Norma ASTM C 457. De forma particular, el trabajo con SEM se concentra sobre el contenido total de aire y el tamaño y la distribución espacial (dentro de la pasta) de los poros.

\section{Reacción álcali-sílice}

La reacción álcali-sílice (ASR) es un fenómeno de degradación del hormigón bien conocido, que ha recibido recientemente una atención renovada. Se sabe, desde hace muchos años, la existencia de aquella reacción y de los mecanismos que la provocan (3-5). Sin embargo, a través de la utilización de técnicas tanto tradicionales como nuevas se consiguen permanentemente nuevas informaciones sobre aquellos mecanismos. Nosotros hemos dirigido nuestros estudios a la identificación de la ettrigita, del gel sílico-alcalino, y de las mezclas detectadas en el hormigón que contiene áridos reactivos. Las cuestiones que deben ser contestadas inciden en: ¿qué es primero, la eitringita o el gel ASR?; ¿cuál es la causa de la rotura del hormigón?

En la literatura clásica de ASR, en la que se utiliza microscopia óptica con secciones pulidas, a menudo se revelan reacciones en los bordes del árido grueso, microfisuras a trevés de las distribution in a non-air entrained concrete thin section, as seen by SEM in (a) BSE mode and (b) against a dark background (for better observability). The largest observable air void is about $0.1 \mathrm{~mm}$. Using a binary image analyzer, the air content of this particular area was determined to be 0.7 percent.

Figure 3 shows similar views for a concrete with higher air content, determined for the area shown to be about 6.3 percent. The maximum entrained air void was found to be about $0.4 \mathrm{~mm}$ in diameter. Using 20 randomly selected areas, the average air content for these samples was found to be 1.6 and 6.5 percent, respectively.

Currently, the routine use of this SEM method for analysis of air voids would be cost prohibitive. However, in complicated cases, the use of the same specimen (in this case a thin section) for determination of air content, crack pattern, microstructure, aggregate mineralogy, presence and location of deleterious products, etc., has merit and, in our experience, is a useful analytical methodology when used in combination with standard testing procedures. A quantitative comparison between the SEM and ASTM C 457 analyses is being developed. In particular, the SEM work focuses on total air content, and size and spatial distribution (within the paste) of air voids.

\section{Alkali-Silica Reaction}

Alkali-silica reaction (ASR), a well-known concrete degradation phenomenon, has recently received renewed attention. For many years, the reaction has been known to exist and its basic mechanisms are known (3-5). However, with the combined use of classical and novel techniques, new information concerning its mechanism is continuously being generated. We have conducted studies on the identification of ettringite, alkali-silica gel, and their mixtures detected in concrete containing aikali-reactive aggregate. The questions to be answered include: Which came first, the ettringite or the ASR gel? What caused the concrete to crack?

As shown in the classical literature on ASR, optical light microscopy using polished sections often reveals reaction rims on coarse aggregate, microcracks through particles, and white ASR gel 
partículas y productos de reacción ASR, gel, de color blanco. Por otra parte, dentro de los poros y en las fisuras se detecta ettringita, generalmente en forma de agujas bien desarrolladas y definidas, cuya observación es sencilla por microscopía SEM.

La figura 4 muestra la superficie obtenida fracturando una muestra de hormigón fisurado a lo largo de la línea de rotura (6). Se observa que alguno de los áridos ha saltado y otras partículas están rotas. Tanto la superficie de fractura del árido, como la correspondiente a los áridos (o al hueco dejado por ellos) están cubiertos por los productos de reacción. Las figuras 5 y 6 muestran tales productos.

La micrografía de la figura 5 está tomada de la superficie de la huella del árido; se puede ver depósitos compactos de ettringita (punto 3) cubriendo una fina capa, no fácilmente detectable, de gel ASR (punto 2) sobre la superficie del árido (punto 1) . La presencia simultánea de gel ASR y de ettringita ha sido descrita recientemente (por ej. 6-7-8). Dependiendo de su localización, dentro del sistema pasta-interfase-árido, puede identificarse tanto el gel ASR, como la ettringita, o bien una mezcla de ambos. La partícula del árido contenía cuarzo microcristalino deformado, posiblemente reactivo a los álcalis.

La figura 6 representa una fractura a través de todo el árido en la misma muestra, con depósito de gel ASR. La ettringita no está presente, dado que la fractura está causada por la formación del gel ASR en los granos de cuarzo microcristalino del árido; tal formación de gel conduce a un debilitamiento y a una eventual fractura de la partícula del árido. La fractura del árido puede no ser causada por reacciones de expansión de la pasta de cemento, tal como sucede con la formación de ettringita causada por la presencia de iones sulfato en el líquido del interior de los poros, ya que la expansión pasta-cemento no puede someter a los áridos a carga a compresión (7).

Se ha de hacer énfasis en el hecho de que se pueden deducir fácilmente conclusiones erróneas si se hace uso sólo de técnicas ópticas o bien sólo de SEM. Por lo tanto, la combinación de diferentes maneras de preparar la muestra (por ejemplo, láminas delgadas, muestras pulidas y superficies de fractura) y diferentes técnicas parecidas (incluyendo espectroscopía de rayos $X$, difracción de rayos $X$, estereomicroscopía, etc.) han resuelto correctamente problemas de durabilidad de determinados hormigones en estudio. reaction products. Ettringite, on the other hand, is usually detected in the form of well-developed, high-aspect ratio needles, easily observable by SEM and light microscopy in air voids or cracks.

Figure 4 shows a surface, obtained by fracturing a sample of cracked concrete along the mapcrack (6). Note that some of the aggregate is pulled out, whereas other particles are fractured. Both the aggregate fracture surface and the pulled-out aggregate surface (or the socket surface) are covered by reaction products. A closer look at these products is given in Figures 5 and 6.

The SEM micrograph in Figure 5 was taken at the pulled-out aggregate surface; it shows heavy deposits of ettringite (point 3) covering a thin, not easily detectable layer of ASR gel (point 2) on the aggregate surface (point 1). Simultaneous presence of ASR gel and ettringite has been recently reported (e.g., 6,7,8). Depending on the location within the paste-interface-aggregate system, ASR gel, ettringite, or a mixture of these can be identified. The aggregate particle was identified as containing substantial amounts of strained microcrystalline quartz, known to be possibly alkali-reactive.

Figure 6 represents a through-aggregate fracture of the same sample, with deposits of ASR gel. Ettringite is not present, because the fracture was caused by formation of ASR gel at the microcrystalline quartz grain boundaries within the aggregate such gel formation leads to weakening and eventual fracture of the aggregate particle. Fracture of the aggregate cannot be caused by reactions causing cement paste expansion, such as by ettringite formation due to presence of sulfate ion in the pore fluid, because cement-paste expansion cannot put the aggregate under compression (7).

We would like to emphasize that if only optical or only SEM techniques had been used, incorrect conclusions could easily have been reached. Because of the combination of different sample forms (e.g., thin sections, lapped samples, and fractured surfaces) and different technical approaches (including $X$-ray spectroscopy, $X$-ray diffraction, stereomicroscopy, etc.), durability issues relevant to the specific concrete under study were correctly resolved. 


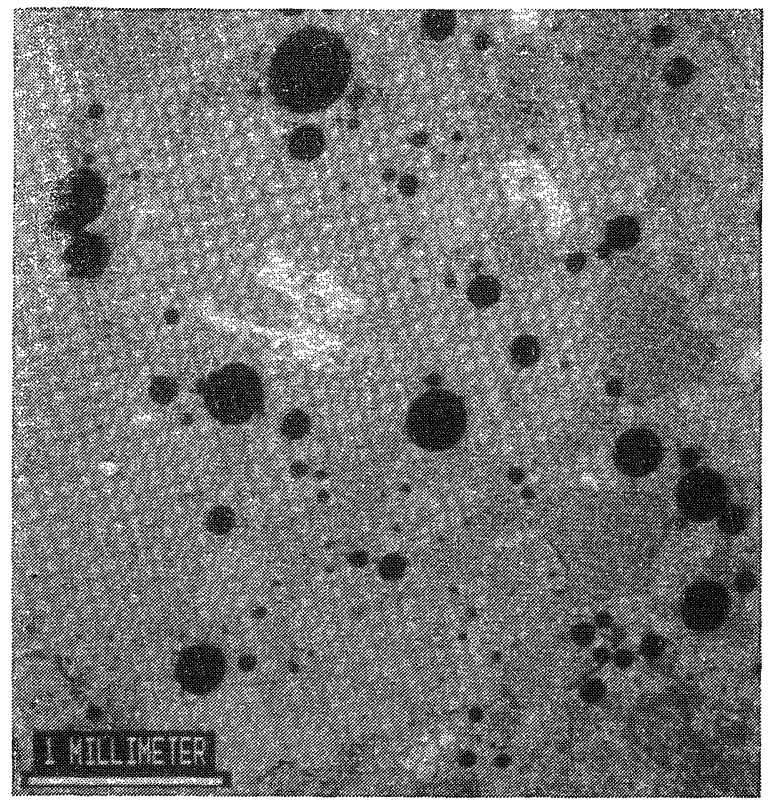

a

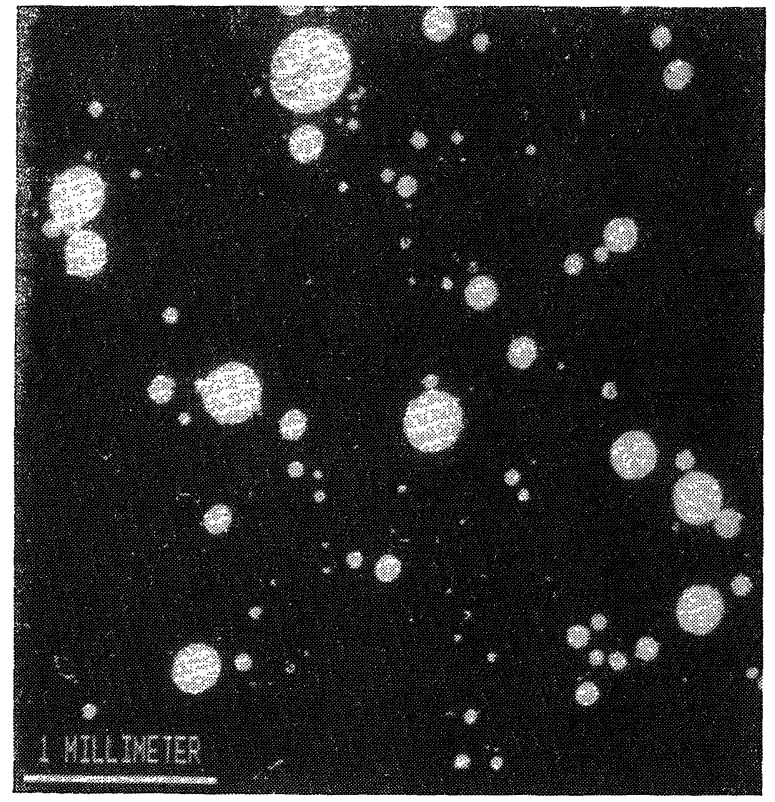

b

Fig. 3.-Distribución de huecos en un hormigón aireado. SEM.

Fig. 3.-Air void distribution in an air-entrained concrete by SEM.

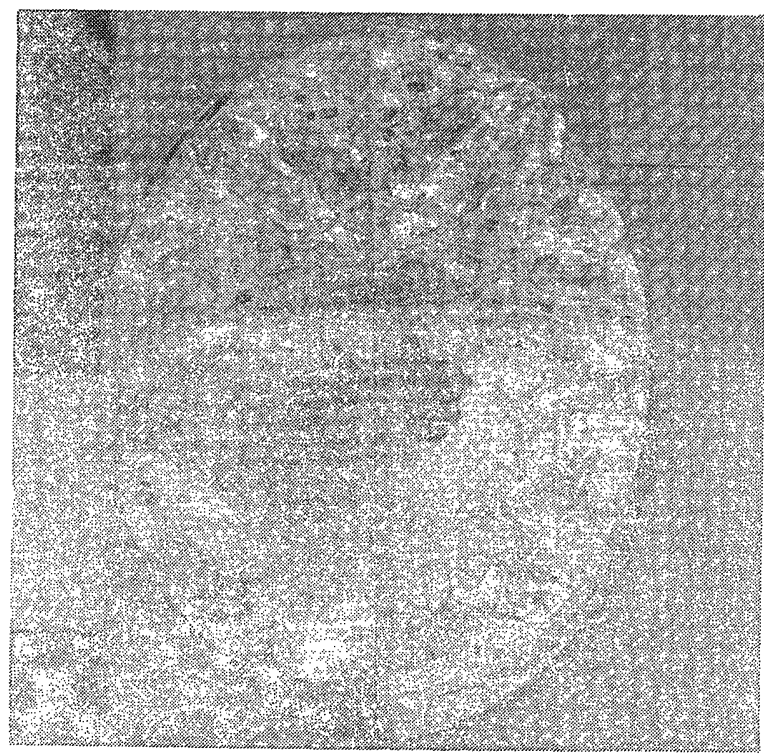

Fig. 4.- Superficies emparejadas de hormigón fracturado a lo largo de la línea de rotura, mostrando superfícies de áridos saltados y áridos rotos. Microscopía óptica.

Fig. 4.-Matching fracture surfaces of concrete exposed along a map crack, showing pull-outs and cracked aggregate. Light microscopy.

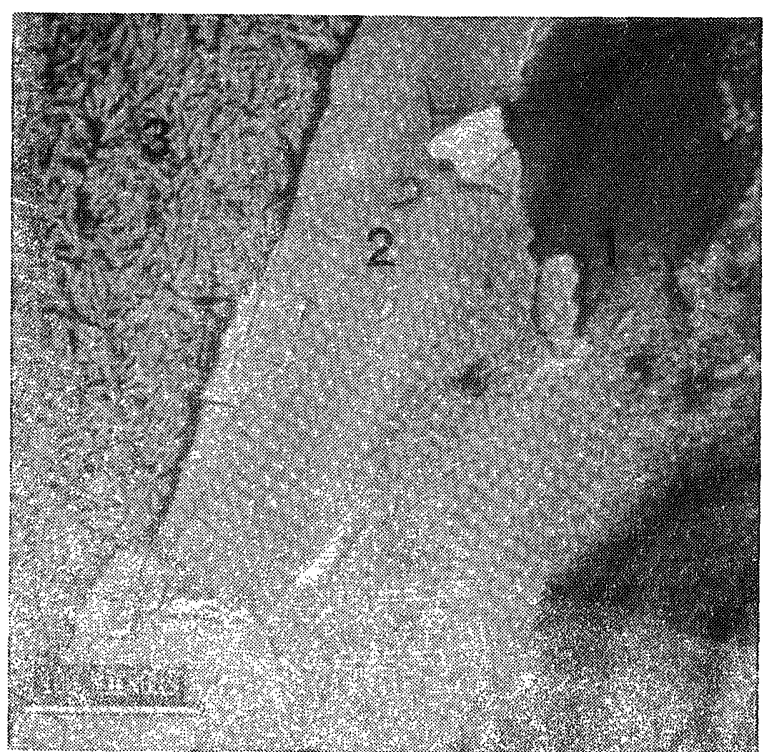

Fig. 5.- Micrografía BSE mostrando gel ASR y ettringita sobre la superfície de los áridos. Imágenes de DRX: 1 - sílice (cuarzo), 2 - gel ASR, 3 - ettringita.

Fig. 5.-BSE micrograph showing ASR gel and ettringite on aggregate surface. $X$-ray images: 1 - silica (quartz), 2 - ASR gel, 3 - ettringite. 


\section{Excesiva temperatura de curado}

El efecto del clima cálido y de la alta temperatura de curado sobre las propiedades físicas del hormigón son conocidas; supone un aumento de la demanda de agua, disminución de los tiempos de fraguado, aumento de la velocidad de pérdida de asentamiento, aumento de la tendencia a formar fisuras en el estado plástico, disminución de la resistencia y durabilidad, etc. Muchos de esos efectos son el resultado de cambios microestructurales causados por el aumento de calor (p.ej., aumento de la velocidad de hidratación, cambios en solubilidades y en velocidades de cristalización) a las primeras edades de curado del hormigón. Otras variables de posible importancia son la presencia de aditivos, calidad del cemento y procedimiento de mezcla.

El objetivo de los trabajos, que se están desarrollando en la actualidad, es conseguir una interpretación de las propiedades físicas de los hormigones a partir de observaciones microestructurales. De forma específica, estamos intentando determinar las condiciones de curado basándonos en la presencia de determinadas observaciones microestructurales realizadas con SEM y "backscattering" en combinación con microscopía de luz transmitida (9).

Se ha dicho (p.ej. 10-11) que durante el curado a elevada temperatura se pueden observar en los hormigones determinadas características microestructurales que son típicas para estas altas temperaturas, y que no aparecen en las muestras correspondientes a temperatura ambiente. La temperatura a la que se desarrollan esos efectos están alrededor de unos 65 a $70^{\circ} \mathrm{C}$. Una característica es la doble tonalidad de los productos de hidratación que están alrededor de la alita $\left(\mathrm{C}_{3} \mathrm{~S}\right.$ sustituido). La diferencia en el nivel del gris está relacionado con la densidad de los productos.

En la figura 7 se pueden ver dos micrografías de muestras de hormigón curado a temperatura ambiente y a alta temperatura, respectivamente (9). La de temperatura ambiente fue curada durante 28 días, a $20^{\circ} \mathrm{C}$; la de alta temperatura se curó durante 4 horas a $100^{\circ} \mathrm{C}$ (en agua hirviendo), y a continuación se hizo un "curado en seco" a $65 \%$ de H.R. y $20^{\circ} \mathrm{C}$ durante 27 dias. Se puede observar la gran cantidad de hidróxido de calcio depositado en los límites pasta-árido en la muestra de temperatura normal; a alta temperatura el grado de hidratación fue más bajo (por ello, hay menos hidróxido cálcico formado y se ve más cemento anhidro) y la porosidad es mayor.

\section{Excessive High-Temperature Curing}

Effects of hot-weather and high-temperature curing on the physical properties of concrete are known and include increased water demand, shorter times of setting, increased rate of slump loss, increased tendency for plastic cracking, decreased strength and durability, etc. Many of the above effects are the consequence of microstructural changes caused by the increased heat input (e.g., increased rate of hydration, changed solubilities and rates of crystallization) at the early stages of concrete curing. Other variables of possible consequence are the presence of admixtures, cement quality, or mixing procedure.

The goal of this particular work in progress is to provide an interpretation of the physical properties of selected concretes on the basis of microstructural observations. Specifically, we are attempting to determine the curing conditions using the presence of microstructural features observed in backscattered SEM mode in combination with transmitted light microscopy (9).

It has been reported (e.g. 10,11) that during high-temperature curing, microstructural features, typical for such high temperatures but not for ambient temperatures, are detectable. The curing temperatures at which these features develop are estimated to be above approximately 65 to $70{ }^{\circ} \mathrm{C}$. A typical feature is the two-toned hydration product around alite (substituted $C_{3} S$ ) particles. The difference in gray level relates to the product density.

Figure 7 compares two laboratory concrete samples cured at normal and high temperatures, respectively (9). The normal temperature sample was cured for 28 days at $20^{\circ} \mathrm{C}$; the hightemperature sample was cured for 4 hours at $100{ }^{\circ} \mathrm{C}$ (in boiling water), followed by "dry"-curing at $65 \% \mathrm{RH}$ and $20^{\circ} \mathrm{C}$ for 27 days. Note the large amount of calcium hydroxide deposited at the paste-aggregate boundaries in the normal temperature sample; at high temperature, the degree of hydration was lower (thus, less calcium hydroxide was formed and more unhydrated material is visible) and the porosity was higher. 


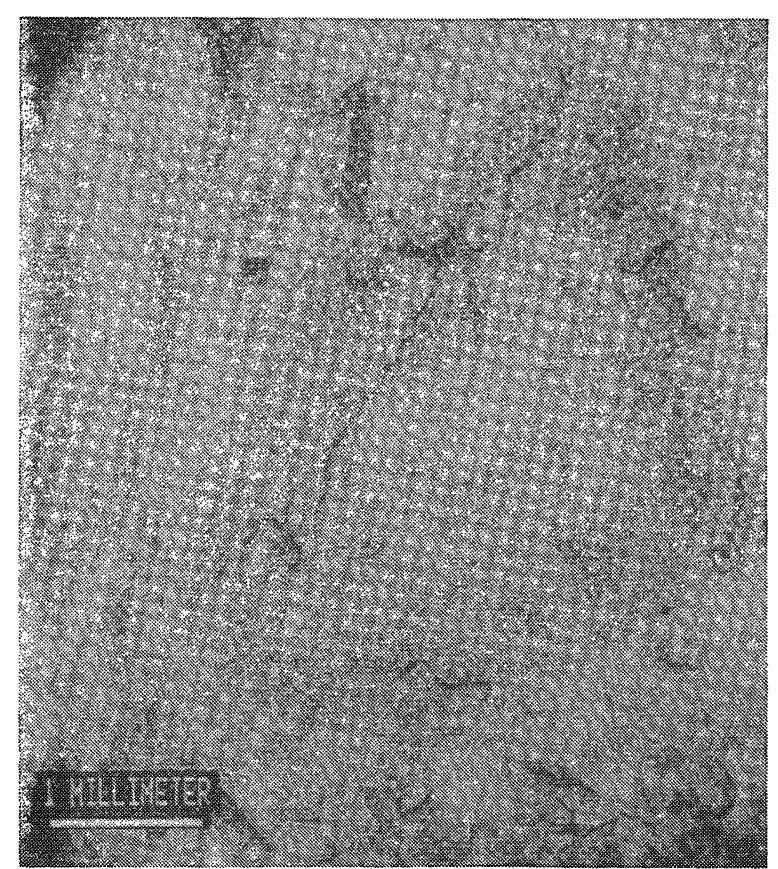

a

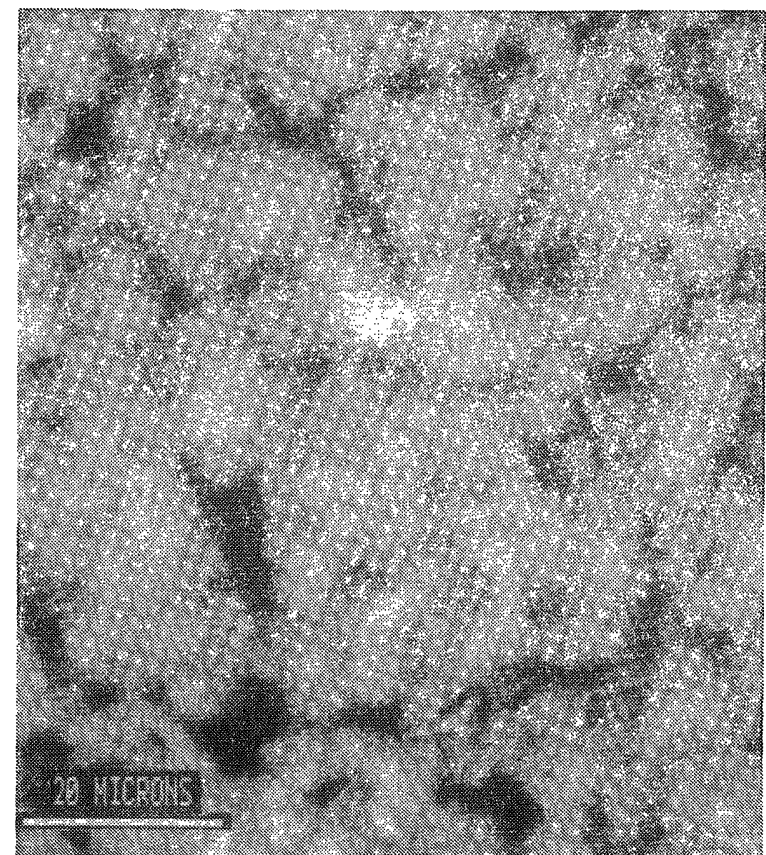

b

Fig. 6.-Micrografía BSE mostrando depósitos de gel ASR sobre la superfície de una fractura transversal de un árido: (a) superfície de la huella de la particula saltada., (b) gel ASR sobre la superfície del árido.

Fig. 6.-BSE micrograph showing deposits of ASR gel on a through-aggregate fracture surface. (a) pulled-out aggregate particle, (b) ASR gel on aggregate surface.

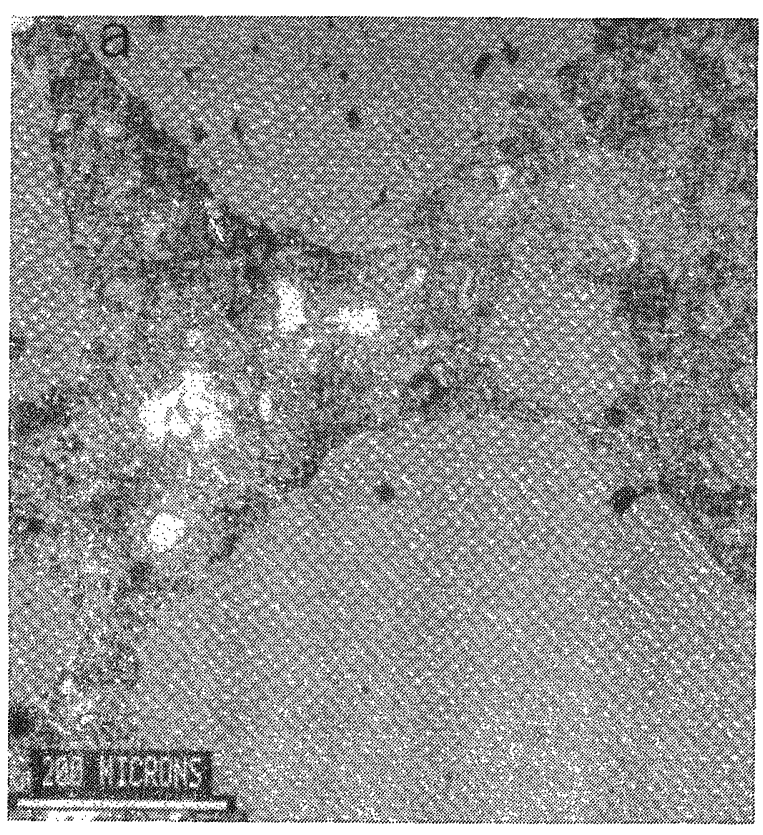

a

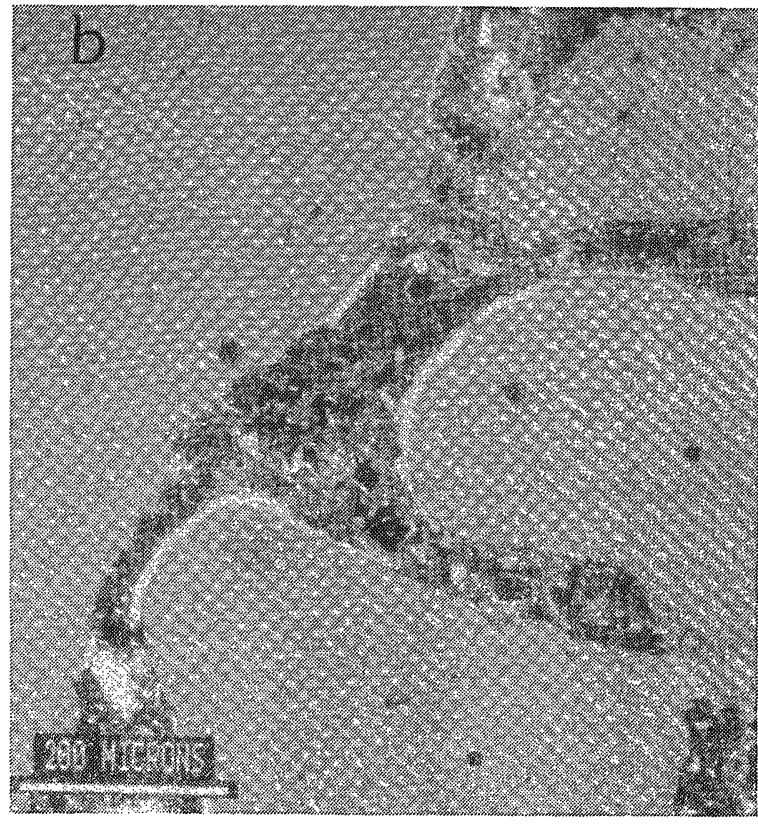

b

Fig. 7.-Micrografías BSE de muestras de laboratorio curadas a temperatura ordinaria (a) y a temperatura elevada (b).

Fig. 7.-BSE micrographs of laboratory samples cured at elevated (a) and normal (b) temperatures. 
La figura 8a es una micrografía SEM de las mismas muestras de hormigón curado a $100^{\circ} \mathrm{C}$. La figura muestra una partícula de alita en la pasta, de gran tamaño, y tan solo hidratada parcialmente que está rodeada por productos de hidratación (silicato cálcico hidratado, C-S-H) con dos tonalidades (a veces también son varias las tonalidades)

Los análisis de rayos $X$ muestran que las capas más exteriores (claras) e interiores (oscuras) tienen la misma composición (igual relación $\mathrm{CaO} / \mathrm{SiO}_{2}$ ) para la sensibilidad que tiene el equipo instrumental utilizado. Así, esas diferencias en la tonalidad (grises) observada a través del modo BSE pueden ser debidas a diferencias en la composición atómica o a la densidad de la muestra; los dos materiales observados deben de diferir en su porosidad (característica inversa de la densidad). La capa más exterior es más densa y corresponde a productos de hidratación formados a alta temperatura durante el tratamiento inicial, mientras que el material más oscuro tiene una mayor porosidad y se cree que su formación se ha producido después del curado. La formación de esa capa densa parece ser la razón del posterior descenso en el grado de hidratación del hormigón curado a altas temperaturas. Esos dos materiales con distinta tonalidad no se observan en hormigones curados a temperatura normal.

Nosotros no creemos que esos productos sean necesariamente equivalentes a los conocidos en la literatura científica como productos de hidratación "interiores" y "exteriores".

La figura 9 muestra la micrografía obtenida a partir de un hormigón comercial producido por curado a aproximadamente $65^{\circ} \mathrm{C}$. Como se puede ver, se aprecian con claridad dos productos de hidratación con tonalidades diferenciadas. Por otra parte, esos materiales con dos tonalidades no se detectan en muestras tratadas a temperaturas por debajo de $65-70^{\circ} \mathrm{C}$.

No está claro, hasta el presente, si esas $u$ otras observaciones que se han hecho (p.ej., "Granos Hadley", "Hollow shells") pudieran ayudar a la determinación de las condiciones de curado o de la historia térmica del hormigón; sin embargo, podría ser factible si se conocen mejor y se relacionan las características microestructurales del hormigón con sus macro-propiedades. Por ejemplo, pudiera ser de interés añadir al hormigón numerosas series de gránulos de alita (u otra fase) del mismo tamaño, para que actúen como indicadores de las condiciones de curado.
Figure $8 a$ is a SEM micrographs of the same concrete sample cured at $100^{\circ} \mathrm{C}$. The figure shows a large, only partially hydrated alite particle in the paste, surrounded by a two-tone (sometimes even multi-tone) layer of hydration product (calcium silicate hydrate, $\mathrm{C}-\mathrm{S}-\mathrm{H}$ ).

$X$-ray analysis shows that the outer (lighter) and inner (darker) layers have the same composition (same $\mathrm{CaO} / \mathrm{SiO}_{2}$ ratio), within the sensitivity of the instrumentation. Because such difference in tone (grayness), as observed in BSE mode, can be caused either by differences in atomic composition or in bulk density, the two observed materials must differ in bulk porosity (reverse of density). The outer layer is denser and represents hydration product formed at the high temperature during early treatment, whereas the more porous dark material is believed to have been formed during the post-curing. The formation of this dense layer may be the reason for the subsequent lower degree of hydration of concrete cured at higher temperatures. Such two tone material is usually not observed in normal-temperature cured concrete (fig. 8b).

We do not believe that these products are necessarily equivalent to the known "inner" and "outer" hydration products discussed in the scientific literature.

Figure 9 shows a micrograph obtained from a commercial concrete product cured at approximately $65^{\circ} \mathrm{C}$. As can be seen, two-tone hydration products are clearly visible. In contrast, the two-tone material is not detectable in samples treated below the temperature of about $65-70^{\circ} \mathrm{C}$.

It is not clear at present whether these or other observed features (e.g., 'Hadley grains', 'hollow shells') can help in the quantitative identification of the curing conditions or thermal history; however, this may become possible once we better understand and relate these microstructural features to the macro-properties of the concrete. Use of supplementary techniques and approaches may be required. For example, it would be interesting to add to the concrete batch large, equally-sized alite (or other) grains to act as tracers of curing conditions. 


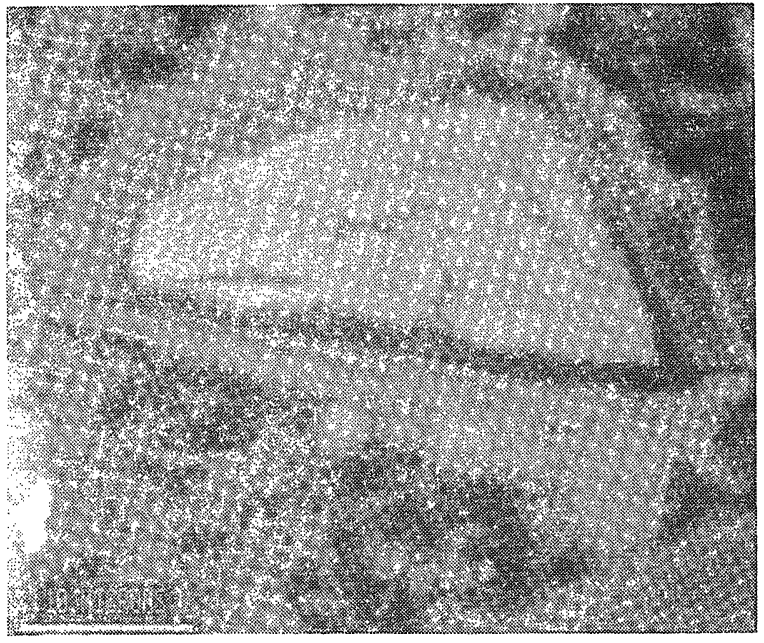

a

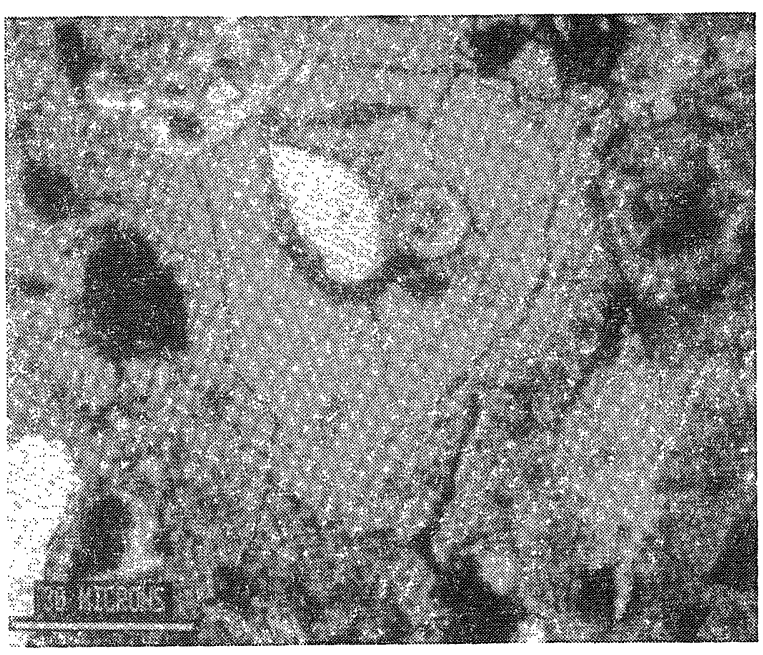

b

Fig. 8.-(a) micrografias de BSE de alita hidratada en hormigones curados a altas temperaturas; (b) a temperaturas normales

Fig. 8.-BSE micrographs of hydrated alite in concrete cured at elevated (a) and normal temperatures (b).

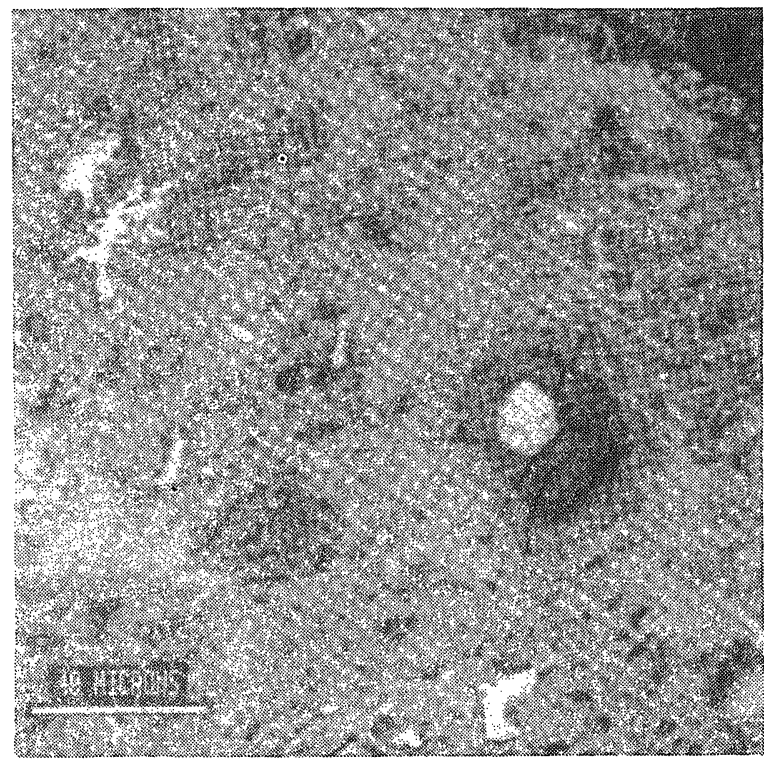

Fig. 9.--Micrografía de BSE en la que se muestran vestigios de productos de hidratación, con dos tonalidades, en un hormigón comercial curado a vapor.

Fig. 9. - BSE micrograph showing two-tone hydration relics in commercial steam cured concrete.

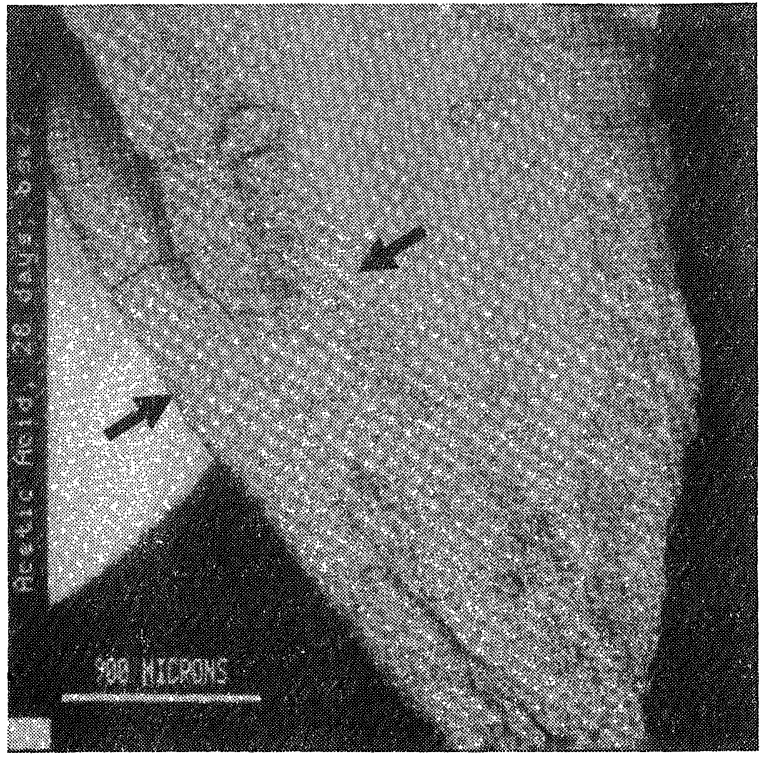

Fig. 10.-Micrografía BSE de un hormigón fracturado en el laboratorio, mostrando el espesor del ataque causado por ácido acético.

Fig. 10.--BSE micrograph of fractured laboratory concrete showing depth of damage caused by acetic acid. 


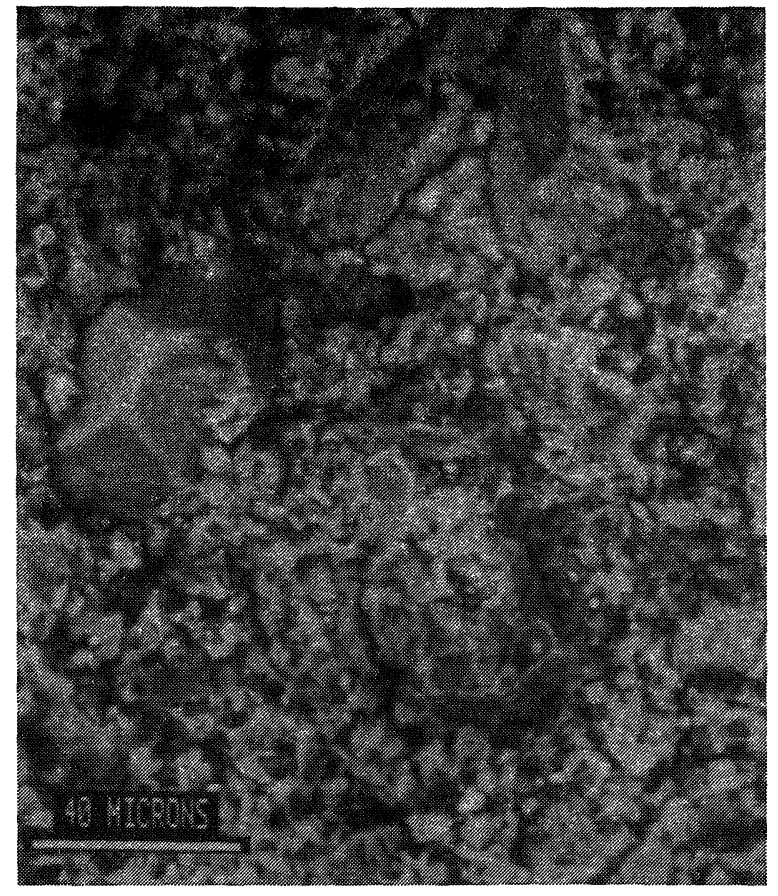

a

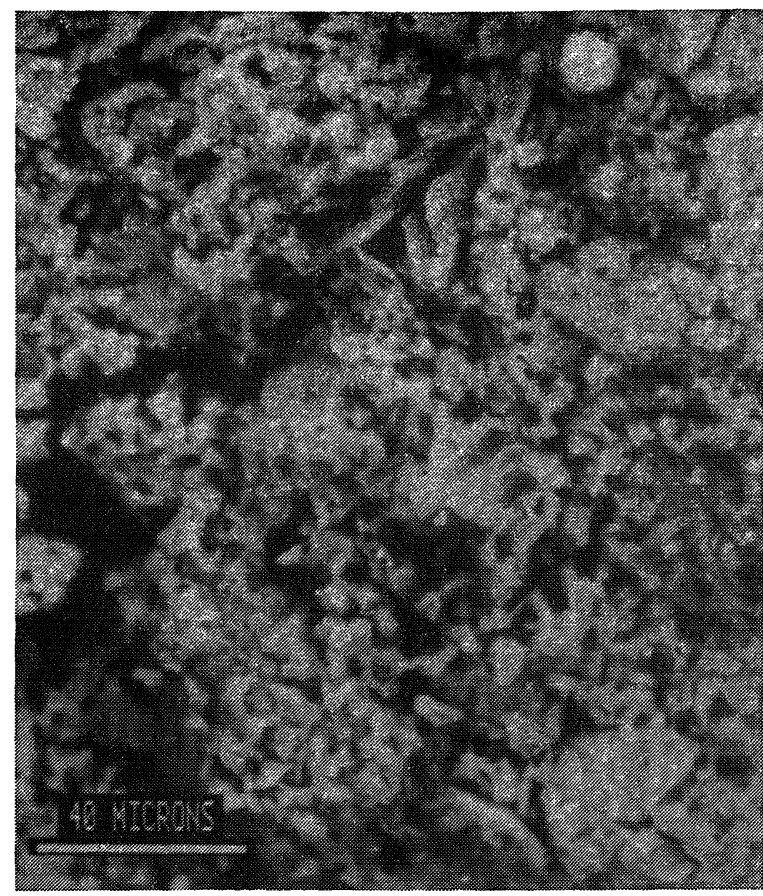

b

Fig. 11.-Micrografía BSE de un hormigón de laboratorio tratado con ácido acético al $5 \%$ : (a) muestra de control, (b) muestra tratada.

Fig. 11.-BSE micrograph of a laboratory concrete treated with $5 \%$ solution of acetic acid: (a) control, (b) treated sample.

\section{Ataque químico}

De igual modo que en otros muchos mecanismos de degradación, la permeabilidad y la porosidad de la pasta juegan un papel crucial en el hormigón. Si se emplea un árido denso, la porosidad total de un hormigón típico - que es la suma de los poros y de los huecos en la pasta de cemento hidratado- está entre el 10 y el $20 \%$ dependiendo de la relación agua/cemento, del contenido de cemento y de su grado de hidratación (12). La porosidad, además, influye en las propiedades mecánicas (como la resistencia) y en las de transporte (permeabilidad, difusibilidad, etc.). La superficie porosa y del hormigón no tratado son más sensibles al ataque químico que en el caso de que las superficies fueran densas o tratadas o tuvieran ambas características.

Ejemplos típicos de degradaciones químicas son: la descomposición de la pasta de cemento en el hormigón en contacto con productos de utilización en la agricultura, tales como urea, ácido láctico, ácido acético, etc. El contacto con tales productos químicos puede producir escamas, expansión o destrucción completa de la estructura del hormigón (p.ej. 13-14).

\section{Chemical Attack}

As is the case with most other degradation mechanisms, porosity and permeability of the paste in concrete play a crucial role. If dense aggregate is used, the total porosity of a typical concrete, which is the sum of the pores and voids in the hydrated cement paste, ranges between 10 and $20 \%$, depending on the water-to-cement ratio $(w / c)$, cement content, and the degree of hydration (12). The porosity, in turn, influences both the mechanical (e.g., strength) and the transport properties (permeability, diffusivity, etc.). Porous and untreated concrete surfaces are more sensitive to chemical attack than are dense or treated surfaces or those that are both dense and treated.

Typical examples of chemical degradation are decomposition of the cement paste in concrete by agricultural chemicals such as urea, lactic acid, acetic acid, etc. Contact of concrete with such chemicals can lead to scaling, expansion, or complete destruction of the concrete structure (e.g., 13,14). 
La figura 10 muestra el espesor de la penetración de una disolución de ácido acético $\left(\mathrm{CH}_{3} \mathrm{COOH}\right)$, en un ensayo de laboratorio $(a / c=0,4)$. La superficie de la fractura (señalada con flechas) está severamente descompuesta y con elevada porosidad.

La figura 11 compara las muestras tratadas y no tratadas a mayor aumento. La micrografía (a) representa la muestra no tratada (curada en agua durante 28 días); la (b), inmersa en una disolución de ácido acético al $5 \%$ durante 28 días, después del curado en agua durante otros 28 días. Los daños al hormigón son causados por la continua disolución del cemento de la pasta matriz. Como era de esperar, las propiedades físicas de este hormigón degeneran rápidamente con el avance de la descomposición de la matriz hidratada (13).

\section{CONCLUSIÓN}

El propósito de este breve trabajo es hacer hincapié en la importancia del estudio multidisciplinar de la diagnosis y de la evaluación del estado de un hormigón. El hormigón es un material demasiado complejo y utilizado en muy diferentes circunstancias y en entornos cambiantes, para depender de un enfoque simplista. Debido a la situación actual de crecimiento de obras de infraestructuras o de reparación de las existentes en todo el mundo, se ha de estimular la utilización de nuevas técnicas y metodologías, rentables y multidisciplinares.
Figure 10 shows the depth of penetration of an acetic acid $\left(\mathrm{CH}_{3} \mathrm{COOH}\right)$ solution into a laboratory concrete $(w / c=0.4)$. The surface of the shown fracture (marked by arrows) is severely decomposed and highly porous.

Figure 11 compares the untreated and treated samples at a higher magnification. Micrograph (a) represents the untreated sample (cured in water for 28 days); micrograph (b) the sample immersed in a $5 \%$ solution of acetic acid for a period of 28 days in addition to 28 days in water. The damage to concrete is caused by continuous dissolution of the cement paste matrix. As expected, the physical properties of this concrete deteriorated rapidly with the progress of decomposition of the hydrated matrix (13)

\section{CONCLUDING REMARXS}

The purpose of this short overwiew is to re-emphasize the importance of a multidisciplinary approach in the forensic evaluation of concrete. Concrete is too complex a material, and used in too many different and changing environments, to depend on simplistic approaches. With increasing emphasis being put worldwide on expanding or rebuilding the national infrastructures, use of novel, cost-effective, and multidisciplinary techniques and methodologies should be strongly encouraged.

\section{ACKNOWLEDGMENTS}

The authors would like to acknowledge cooperation of B. A. Clark, R.J. Lee, Yuan Jie, R. J. Schwoeble, and D. A. Warner. Thanks are also due to A. Bajza of the Slovak Technical University in Bratislava for supplying some of the chemically corroded samples.

\section{REFERENCIAS}

\section{REFERENCES}

(1) R. J. LEE, A. J. SCHWOEBLE, K. E. WAGNER AND YUAN JIE: "Integration of Multiple Advanced Analytical Techniques to Study Alkali Silica Reactivity in Concrete Railroad Ties", in Proc. 1991 Eng. Found.Conf. on Adv. Prod. Util. of Cement-Based Matls., Potosi, MO, in press.

(2) K. E. WAGNER, E. A. DRAPER, and J. SKALNY: "Use of Complementary Imaging Techniques In Concrete Deterioration Studies", MRS Bulletin, March 1993, 60-65.

(3) G. M. IDORN: Durability of Concrete Structures in Denmark, Thesis, Technical University of Denmark, Copenhagen, 1967.

(4) S. DIAMOND: "ASR - Another Look at Mechanisms", in Proc. 8th Int.Conf. on Alkali-Aggregate Reaction, 83-94; Kyoto, 1989. 
(5) R. HELMUTH and D. STARK: "Alkali-Silica Reactivity Mechanisms", in Materials Science of Concrete III, The American Ceramic Society, Westerville, $\mathrm{OH}, 1992,131-208$.

(6) B. A. CLARK, A. J. SCHWOEBLE, R. J. LEE and J. SKALNY: "Detection of ASR in Opened Fractures of Damaged Concrete", Cem.Concr.Res.22(1992), 1170-1178.

(7) V. JOHANSEN, N. THAULOW and J. SKALNY: "On the Simultaneous Presence of Alkali-Silica Gel and Ettringite in Concrete", Advances in Cement Research 5(1993), 23-29.

(8) R. E. OBERHOLSTER, H. MAREE, and J. H. B. BRAND: "Cracked Prestressed Concrete Railway Sleepers: Alkali-Silica Reaction or Delayed Ettringite Formation", in Proc. 9th Int. Conf. on Alkali-Aggregate Reaction, The Concrete Society, London, July 1992, 739-749.

(9) B. A. CLARK, E. A. DRAPER, R. J. LEE, J. SKALNY, M. BENBASSAT and A. BENTUR: "Electron-Optical Evaluation of Concrete Cured at Elevated Temperatures", in Durable Concrete in Hot Climates, ACI SP-139, 1993, 41-59.

(10) N. THAULOW: "Microscopy. The Inside Story of Concrete", First Euroseminar on Microscopy Applied to Building Materials, Copenhagen, June 1987.

(11) K. O. KJELLSEN, R. J. DETWILER and O. E. GJORV: "Development of Microstructures in Plain Cement Pastes Hydrated at Different Temperatures", Cem.Concr.Res.21 (1991), 179-189.

(12) H. W. REINHARDT: "Transport of Chemicals Through Concrete", in Materials Science of Concrete III, The American Ceramic Society, Westerville, $\mathrm{OH}, 1992,209-241$.

(13) A. BAJZA, I. ROUSEKOVA, and O. VRANA: "Corrosion of Hardened Cement Pastes by $\mathrm{NH}_{4} \mathrm{NO}_{3}$ Solutions", in Proc . 8th Int. Congr. Chem. Cement, Rio de Janeiro, 1986, Vol.5, 99.

(14) A. L. HARNER, C. H. COPELAND, and B. G. CRIM: "Destruction of Concrete by Fertilizers - Urea Ammonium Nitrate vs. Concrete", in Proc. 14th Int. Conf. on Cement Microscopy, Costa Mesa, CA, 1992, 53-63.

\section{publicación del ICCET/CSIC}

\section{INSPECCION DE OBRAS DAÑADAS POR CORROSION DE ARMADURAS}

El presente Manual va dirigido principalmente a técnicos especializados y laboratorios que tienen que intervenir en el dictamen de la situación de deterioro de estructuras de hormigón armado dañadas por corrosión de armaduras.

Comienza con un resumen recordatorio de los factores principales a los que se pueden deber los daños prematuros por corrosión de armaduras, para seguir con algunas indicaciones de cómo se deben realizar las inspecciones, y de los ensayos y la metodología que se recomienda realizar para poder dictaminar con precisión las causas de daño.

A continuación se hacen una serie de comentarios sobre la vida residual de estructuras dañadas, sobre el riesgo de corrosión futura, el seguimiento necesario de una estructura reparada y una breve enumeración de métodos de reparación y consideraciones básicas a tener en cuenta en la recomendación de un determinado método. Se aporta una breve relación bibliográfica.

Finalmente se incluyen en forma de ficha la descripción de algunos casos de corrosión de armaduras detectados en nuestro país.

\section{manual} inspección de obras dañadas por corrosión de axmaduras 